\title{
Pesticide regulation in South Africa
}

\author{
By \\ I. H. WIESE * and J. Bot * *
}

\section{Contents}

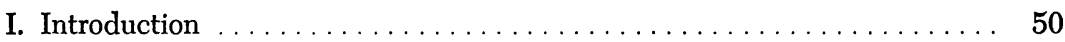

II. Legislation administered by the Department of Agricultural

Technical Services ............................... 50

a) Registration in terms of the Fertilizers, Farm Feeds and Remedies Act (Act 36 of 1947) .................... 50

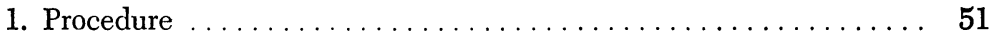

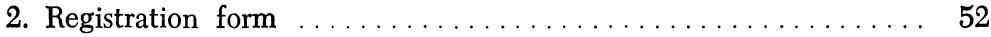

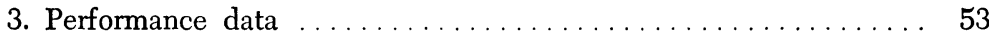

4. Toxicological data $\ldots \ldots \ldots \ldots \ldots \ldots \ldots \ldots \ldots \ldots \ldots, \ldots \ldots$

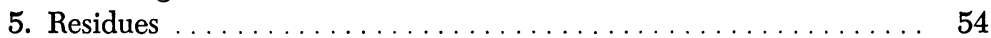

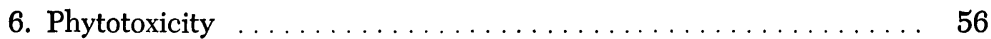

7. Formulations and application methods $\ldots \ldots \ldots \ldots \ldots \ldots \ldots, 56$

8. Labelling and advertising $\ldots \ldots \ldots \ldots \ldots \ldots \ldots \ldots \ldots$

9. Packaging and transport $\ldots \ldots \ldots \ldots \ldots \ldots \ldots \ldots \ldots \ldots \ldots \ldots$

b) Regulatory and enforcement programme $\ldots \ldots \ldots \ldots \ldots \ldots \ldots . \ldots 5$

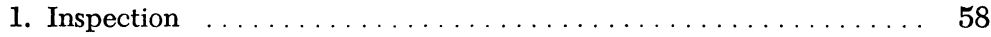

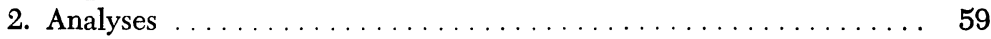

III. Legislation administered by the Department of Agricultural

Economics and Marketing ......................... 59

a) Inspection in terms of the Fruit Export Act (Act 27 of 1957)
and the Agricultural Produce Export Act (Act 10 of 1959) ....... 59

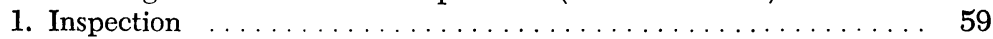

IV. Legislation administered by the Department of Health .......... 60

a) Medical, Dental and Pharmacy Act (Act 13 of 1928) ........... 60

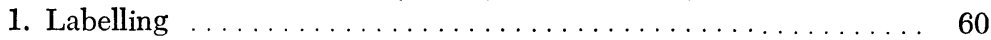

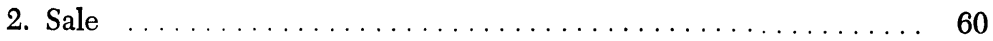

b) Public Health Act (Act 36 of 1919) ................... 61

1. Notification of poisoning $\ldots \ldots \ldots \ldots \ldots \ldots \ldots \ldots \ldots, 61$

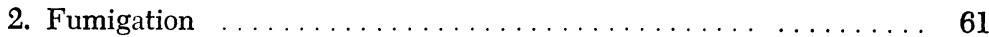

c) Foods, Drugs and Disinfectants Act (Act 13 of 1929) .......... 62

1. Limits to toxic substances in preparations $\ldots \ldots \ldots \ldots \ldots \ldots .62$

* Directorate of Agricultural Research, Department of Agricultural Technical Services, Pretoria.

* Plant Protection Research Institute, Department of Agricultural Technical Services, Pretoria. 
Summary $\ldots \ldots \ldots \ldots \ldots \ldots \ldots \ldots \ldots \ldots \ldots \ldots \ldots \ldots, \quad 62$

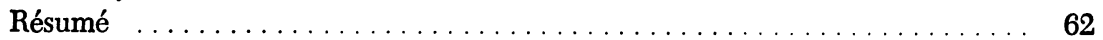

Zusammenfassung $\ldots \ldots \ldots \ldots \ldots \ldots \ldots \ldots \ldots \ldots \ldots \ldots, 63$

\section{Introduction}

Legislation pertaining specifically to the sale of pesticides in South Africa was first promulgated more than half a century ago when the Fertilizers, Farm Foods, Seeds and Pest Remedies Act was passed in 1917. The aim of this Act was to deter the sale of undergrade remedies thus protecting the farmer from potential commercial exploitation. This Act was replaced by more sophisticated legislation in 1947 when the Fertilizers, Farm Feeds and Remedies Act (Act 36 of 1947) was promulgated and which is still operative today. Regulations in respect of the compulsory registration and sale of veterinary remedies appeared under Government Notice 1155 of 4 June, 1948 and in respect of agricultural remedies under Government Notice 1243 of 25 May, 1951, the latter being amended by Government Notice R406 of 18 August, 1961 and substituted by Government Notice R944 and R945 of 17 June, 1966.

In addition to the above-mentioned Act which is administered by the South African Department of Agricultural Technical Services, the Department of Health of the Republic of South Africa administers certain legislation where pesticides impinge on the field of public health. The Medical, Dental and Pharmacy Act (Act 13 of 1928) places certain restrictions on scheduled "poisons", the Public Health Act (Act 36 of 1919) requires that incidents of pesticide "poisoning" be reported as a "notifiable disease", while the Foods, Drugs and Disinfectants Act (Act 13 of 1929) establishes maximum quantities of certain elements which may be present in foodstuffs. Furthermore, in terms of the Fruit Export Act (Act 27 of 1957), the Department of Agricultural Economics and Marketing sets certain standards in respect of pesticidal residues on export commodities.

As opposed to many other countries, no legislation pertaining to pesticides is operative at state or provincial level, all provinces being subject to legislation enacted by the central government.

\section{Legislation administered by the Department of Agricultural Technical Services}

\section{a) Registration in terms of the Fertilizers, Farm Feeds and Remedies Act (Act 36 of 1947)}

The Fertilizers, Farm Feeds and Remedies Act provides for the appointment of a Registering Officer who, as an officer of the Department of Agriculture, is charged with the duty of registering remedies, "remedy" being defined as "any substance which is intended or offered 
to be used for the destruction of any noxious plant or insect, or in regard to domestic animals, livestock or plants, for the prevention treatment or cure of any disease, infestation or other unhealthy or unfavourable condition, or for the maintenance of health, but not including any substance, prescribed by a veterinarian for a specific patient or group of patients."

In the regulations pertaining to stock remedies, the definition is not further amplified, but in the case of agricultural remedies, the definition of agricultural remedy is paraphrased as "any eelworm remedy, legume inoculant, wood preservative, insecticide, weed killer, defoliant, plant growth regulator, fungicide, desiccant or any virus remedy." Of interest is that the above-mentioned definition does not confine the registration to remedies used in agriculture but also provides for the registration of products intended for domestic and public health use. Furthermore the definition of "remedy" does not cater for rodenticides, attractants, or repellents and to date these products are exempt from registration.

By and large the regulations for stock and agricultural remedies prescribe fairly similar requirements and for the purpose of this paper the emphasis throughout will be on agricultural and public health remedies.

1. Procedure.--All applications for the registration of remedies must be submitted under cover of the completed registration form and the prescribed fee paid to the Registering Officer. In addition to two samples of the remedy, the application must be accompanied by experimental data in support of efficacy, full pharmacological and toxicological data, methods of macro- and microanalysis and, where applicable, residue and phytotoxicity data under South African conditions. Typed copies of the proposed label and advertising material must also be submitted.

Upon receipt, the Registering Officer forwards the application to the Technical Adviser concerned who is a specialist officer in that specific sphere. The Technical Adviser scrutinises the application and may in turn solicit the comments of any of his colleagues not attached to the pesticide industry. He may also communicate directly with the applicant and request further data. The onus is on the applicant to satisfy all requirements, but the Department reserves the right to, where necessary, first conduct its own experimental work prior to registration approval. When satisfied, the Technical Adviser returns the application to the Registering Officer recommending registration of the product.

Prospective applicants are encouraged to approach the Technical Advisers before launching their experimental programme with the view to discussing details of experimental requirements. At this stage prospective applicants are also advised to submit samples of the material to Departmental research institutes concerned with the crop or pest for which they anticipate seeking registration so that these institutes 
can include the product in their own experimental programmes. Furthermore, the applicants are advised to invite officers from such research institutes as well as the liaison officer of the office of the Technical Adviser concerned to inspect their own experiments from time to time when these are in progress.

Use of Departmental experimental data in support of an application can only be made once such findings have been published in a recognized scientific journal. Only under exceptional circumstances where it is impossible for the applicant to undertake the required research without Departmental support, e.g., treatment of grain in bulk storage or control of certain forest pests, will the applicant, following close co-operation with the Department, be permitted to refer to unpublished Departmental data in support of registration claims.

All registrations expire on a fixed date every four years. Where no amendments to an existing registration are contemplated and no additional claims are made, re-registration requires the submission of the completed application form, label, and re-registration fee only. Any amendment or additional claim made during the registration period or at the time of re-registration requires the submission of a full complement of data as outlined above.

Whenever an application for registration is rejected or made subject to conditions set by the Registering Officer, the applicant may within 14 days of being notified of such objection or cancellation apply to the Registering Officer in writing for the reasons for such decision. The Registering Officer shall, within 14 days of receipt of such application, furnish the applicant in writing with such reasons. Should the applicant not be satisfied with the reasons provided he may within 56 days of being notified of such objection or cancellation appeal to the Minister in writing against such decision.

Remedies imported for personal use and not destined for sale are not subject to the compulsory registration procedure, but importation depends on the written approval of the Registering Officer. In the case of commercial organisations importing remedies with the view to sale the Registering Officer may issue a general permit requiring a declaration of the required information at annual intervals. Importation of experimental remedies is subject to the written approval by the Registering Officer. Applications for such imports must be accompanied by details as to land of origin, port of entry, quantities imported, purposes for which the remedy will be used, and where the remedy is to be tested.

2. Registration form.--On this form the applicant is required to furnish, amongst other details, the following information: name and South African address of applicant seeking registration and whether said applicant is responsible for the importation, manufacture, or sale of the proposed remedy. Full composition statement expressed on a 
weight/weight basis both for solid and liquid formulations. Where the applicant is only seeking registration for the sale of the product, and cannot obtain the full composition statement because the manufacturer is not prepared to divulge this information, the manufacturer is required to submit this information direct to the Registering Officer, all technical details being considered as strictly confidential. Trade name which must be readily distinguishable from any other trade or brand name. A statement of properties claimed for the remedy and full directions for use. Lastly, the oral $\mathrm{LD}_{50}$ to the rat of the technical material, precautionary measures, symptoms of poisoning, and antidote must be indicated.

3. Performance data.-- The prime requisite for registration is that the product be "suitable and sufficiently effective" for the purpose for which it is intended. Experimental data in support of claims made should be derived from experimentation stretching over at least two and preferably three seasons and research should be conducted under varying climatic conditions in areas of the country where the remedy will be applied. In most cases experimental work must include a control and where other remedies have been registered for the control of a certain pest on a specific commodity at least the most generally used product should be included as a standard against which the candidate product will be evaluated. The candidate product should be applied at varying dosage rates which will permit the establishment of threshold efficacy and the determination of an optimum dosage rate. Results are generally based on the efficacy of the product in reducing pest numbers, but where this is not feasible, e.g., in the evaluation of nematocides, damage, quality, or yield differences of the crop become acceptable criteria. Where the timing of applications is important or where repeated treatments are to be effected entire pesticidal programmes must be compared to determine the significance of a proposed product in such a programme. All experimental work must be conducted on a sound biometrical basis and results subjected to statistical analysis. Needless to say, the design will depend on circumstances and will range from a simple analysis of variance to complex factorial designs.

Efficacy data of a product to a specific pest species has to be submitted on every crop on which control is claimed. Only under exceptional circumstances will the applicant be permitted to extend the range of crops on which control is claimed upon submitting efficacy data on one specific crop only. Such exceptions will include, for example, the control of cutworms by means of bait treatment. Overseas data are not acceptable although these are welcome in support of registration.

In terms of Act 36 of 1947, economic aspects of a pesticide do not enter the picture where registration is concerned. Provided the product 
is efficacious the cost involved will not deter from its acceptability. This may have shortcomings especially in a Department such as that administering the Act where economic aspects are of prime significance.

4. Toxicological data.--A pesticide is accepted for registration only when information is available to demonstrate clearly that its proposed use, when directions are followed, will not cause any prohibitive hazards. Since the inception of the registration scheme, toxicological requirements have been becoming increasingly sophisticated. Required data include the acute oral toxicity to a variety of mammals and birds, essentially the rat; chronic toxicity following exposure at varying dietary intakes for prolonged periods including three-generation studies on at least one mammal; and acute dermal toxicity to at least one mammal as well as skin and eye irritation. Furthermore, in the case of fumigants or products exhibiting a high vapour pressure, data on fumigant toxicity must be submitted. Where products are to be used in conjunction with other pesticides, such products must be checked out for possible potentiation. Potential carcinogens and teratogens are not accepted for registration.

If the Technical Adviser to the Registering Officer is satisfied that the pesticide in question is efficacious for the purpose claimed and offers no undue hazards when used as recommended he forwards all toxicological data and the draft label together with his comments and recommendations as to the desirability of registration and proposed precautionary statements, tolerance, and safe periods to be observed to the Standing Advisory Committee on Pesticides. This Committee, which consists of representatives from the Departments of Health and Agricultural Technical Services and meets at monthly intervals is burdened with making recommendations as to the desirability of registration from a human hazard point of view. The Committee communicates its decision to the Technical Adviser who in turn submits his recommendations to the Registering Officer.

In the case of a pesticide which has not been registered in this country, the applicant may submit all toxicological data together with proposed use to the Advisory Committee to obtain an idea of possible acceptability before commencing efficacy trials.

At present facilities for clearing a pesticide from an environmental contamination point of view are inadequate. In South Africa wildlife research and nature conservation are the function of the individual provincial administrations, there being no federal body to co-ordinate these activities. Accordingly, the Department of Agricultural Technical Services has been compelled to evaluate the environmental hazard of pesticides on an ad hoc basis. More intensive research in this sphere is, however, urgently called for.

5. Residues.--Whenever a product is to be applied to an edible commodity or where its proposed use will result in the contamination of foodstuffs, the applicant is obliged to submit residue data obtained 
under local conditions before registration can be considered. These residue determinations may be undertaken by any party, normally by the applicant himself or by his overseas principals to whom the samples are consigned in a deep-frozen state. Alternatively the residue analyses may be undertaken by a third party such as the South African Bureau of Standards or commercial analytical organisation, which, at a fee, provide a residue analytical service to the agricultural industry.

Residue data submitted in support of registration claims should present a full degradation pattern. Initial deposits on the crop must be determined followed by analyses at progressively longer intervals to beyond the proposed tolerance value. Such data will permit possible extrapolation should the necessity for this arise. Where the cost of residue analysis is high, residue determinations at at least three time intervals is the minimum requirement. Representative field samples should be drawn sufficiently large to permit subsequent subsampling. Where the commodity to be analysed is intended for human consumption it should be dressed as for marketing. Where the pesticide distribution in the commodity is expected to vary in different tissues, such tissues should be analysed separately. For instance, in citrus fruit residues of lipophilic pesticides are expected primarily in the peel and only small amounts in the pulp. Presenting individual residue figures enhances the value of the data, but tolerances are based on the "raw agricultural commodity" as it is offered for sale. Residue data should be accompanied by the analytical method employed, recoveries from fortified samples in the residue range expected, and limits of detection of the pesticide on the particular commodity. Needless to say, where intermediate degradation products are formed, residues of these, too, should be presented.

In general, tolerances laid down by the Food and Drug Administration of the United States Department of Health, Education and Welfare are accepted in South Africa and safe periods to be observed following pesticidal applications are determined accordingly. In the event of the U.S. Food and Drug Administration not having established a tolerance, values set in either The Netherlands or in West Germany are accepted. If no tolerances have been established in any of the above-mentioned countries the setting of a value may be considered by the Standing Advisory Committee on Pesticides when adequate toxicological and residue data are available. With the recent enforcement of tolerances by several European countries, which in general are considerably lower than those of the U.S. Food and Drug Administration, the Department of Agricultural Technical Services has been obliged to extend safety periods of pesticides to accommodate overseas markets. As a result double standards for produce consumed locally and that destined for export have been introduced particularly in citrus and deciduous fruit cultures, an arrangement which is not ideal.

Should residues of more than one pesticide from the same class of 
pesticides exhibiting a similar mode of action in mammals be present on a commodity-three identified classes being the chlorinated hydrocarbons, the dinitro compounds, and the organophosphorus compounds (including the carbamates) - the tolerance for the total of such residues shall be the same as that for the chemical having the lowest numerical value in that class. Where residues of two or more compounds in the same class can be identified separately the percentage permissible residue is determined and upon summation should not exceed 100 percent.

6. Phytotoxicity.--In the efficacy evaluation of a pesticide, routine checks on possible phytotoxicity should be made especially at higher dosage rates. Where a product is to be applied to a crop of which known phytotoxicity-susceptible cultivars are cultivated, i.e., sorghum and deciduous fruit, separate phytotoxicity studies have to be undertaken on these cultivars with all formulations which will be applied in practice. In the event of products showing up phytotoxic symptoms, precautionary statements must appear on the label.

7. Formulations and application methods.-- Most performance tests are conducted using either wettable powder or emulsifiable concentrate formulations. Should an applicant wish to register a formulation different from the one used in the performance tests, further data obtained during a single season in which the new formulation is compared with the registered one must, where applicable, be submitted together with residue and phytotoxicity data. Likewise a distinction is made between ground application (high- and low-volume), aerial application, and ultra-low-volume application. Again the applicant is required to furnish the Registering Officer with proof that the performance of the remedy is satisfactory in the case of an application method other than that employed in efficacy trials on which registration was granted. Provided the dosage remains constant no further residue data are required, except in the case of ultra-low-volume application.

8. Labelling and advertising.-- The sale of any agricultural remedy which does not bear the approved label on the container is prohibited. All information marked or printed on a container must appear on one composite label; separate stickers bearing additional information are not permitted. Only in exceptional cases where the container is too small or unsuited for printing may the directions appear on a loose leaflet which must, however, be packed with the container.

All labels are approved by the Technical Adviser and their wording may not be changed without his prior consent. No regulations are laid down as to the layout or letter size of the label, but instructions on how to best draw up a label to the Registering Officer's satisfaction are available to potential applicants. According to the regulations the following must appear clearly and legibly on the label: trade or brand name followed in brackets by the common name(s) of active ingredient(s), net weight or volume, composition statement, properties and 
purpose for which the remedy is intended, directions for use and precautionary statement, and registration number and reference to the Act and the address of the person(s) responsible for registration. Registration of the remedy will only be effected upon receipt of printed copies of the approved label.

In order to distinguish between the acute toxicity of pesticides, four groups are recognised. The basis for this classification is outlined in Table I.

Table I. Basis for classification of pesticides according to toxicity

\begin{tabular}{|c|c|c|c|c|}
\hline Group & $\begin{array}{l}\text { Acute oral } \\
\mathrm{LD}_{50} \\
\text { (rat) }\end{array}$ & $\begin{array}{l}\text { Acute dermal } \\
\mathrm{LD}_{50} \\
\text { (rat) }\end{array}$ & $\begin{array}{l}\text { Acute inhalation } \\
\mathrm{LD}_{50} \\
\text { (rat) }\end{array}$ & $\begin{array}{l}\text { Tech- } \\
\text { nical } \\
\text { mate- } \\
\text { rial }\end{array}$ \\
\hline I & \multicolumn{3}{|c|}{$\begin{array}{l}<50 \mathrm{mg} . / \mathrm{kg} \text {., } O R<200 \mathrm{mg} . / \mathrm{kg} ., O R<2 \mathrm{ml} . / \mathrm{L} \text {. or any } \\
\text { pesticide which, though exhibiting a toxicity not in- } \\
\text { cluded in this category, provides sufficient hazard to } \\
\text { warrant placing in this group }\end{array}$} & I \\
\hline $\begin{array}{l}\text { II } \\
\text { III }\end{array}$ & $\begin{array}{l}50 \text { to } \\
500 \mathrm{mg} . / \mathrm{kg} . \\
500 \text { to }\end{array}$ & $\begin{array}{l}\text { OR } 200 \text { to } \\
2,000 \mathrm{mg} \cdot / \mathrm{kg} . \\
\text { OR } 2,000 \text { to }\end{array}$ & $\begin{array}{l}\text { OR } 2 \text { to } \\
20 \mathrm{ml} . / \mathrm{L} . \\
\text { OR } 20 \text { to }\end{array}$ & $\begin{array}{l}\text { II } \\
\text { III }\end{array}$ \\
\hline IV & $\begin{array}{r}5,000 \mathrm{mg} \cdot / \mathrm{kg} . \\
>5,000 \mathrm{mg} \cdot / \mathrm{kg} .\end{array}$ & $\begin{array}{c}20,000 \mathrm{mg} . / \mathrm{kg} \\
\mathrm{AND}>20,000 \\
\mathrm{mg} . / \mathrm{kg}\end{array}$ & $\begin{array}{c}200 \mathrm{ml} . / \mathrm{L} . \\
\text { AND }>200 \mathrm{ml} . / \mathrm{L} .\end{array}$ & IV \\
\hline
\end{tabular}

The most toxic group requires the words "POISON EXTREMELY TOXIC" to appear in red letters the size of which is not to be less than half that of the name of the product on a contratsing background on the main panel of the label and the skull and crossbones; the second group requires the word "POISONOUS," and the third group requires the word "CAUTION" in similar print. The least toxic group requires no reference to toxicity but indication that a product may be safe is not permitted either on the label or in advertising material. The labelling of toxic pesticides is also subject to the requirements set out under health legislation in a latter section.

In terms of the regulations every person who issues an advertisement of an agricultural remedy must within 14 days of the first publication thereof submit a typed or printed copy thereof to the Registering Officer. The use of words or phrases calculated to lead a purchaser to believe that registration implies special approval or official guarantee of efficacy on the part of the Department of Agricultural Technical Services is not permitted, nor are claims other than those approved of in the registration certificate permitted to be included in advertising material. 
9. Packaging and transport.--Highly toxic remedies must be packed in accordance with the requirements of the South African Bureau of Standards' Specification 050-1964 in order to minimize hazards of food contamination in the process of handling, transport, and storage. The South African Railways prescribes requirements set in SABS 060-1969 for the transport of remedies.

\section{b) Regulatory and enforcement programme}

1. Inspection.-- Under the Fertilizers, Farm Feeds and Remedies Act (Act 36 of 1947) inspectors are appointed to investigate any reported malpractices under the Act and also to take routine samples for quality control. An inspector may at all reasonable times enter upon any premises, place, vehicle, or vessel at or in which there is reasonable grounds suspected to be any remedy. He may inspect any machinery utilised in connection with the manufacture of any remedy, or any book, record, or document found in or upon such premises, place, vehicle, or vessel. He may seize any remedy or any books, records, or documents found in or upon such premises, place, vehicle, or vessel which appear to afford evidence of the contravention of any provision of the Act and take as many samples or such quantities as he may deem necessary for the purpose of examination or analysis.

All samples taken must be in the presence of the person in charge of such remedies or in the absence of such person in the presence of any other witness. Where the remedy to be sampled is in bulk storage, the inspector takes a representative sample, which after thorough mixing is divided into three parts, each sufficient for the purpose of analysis. Each part is sealed and thoroughly labelled. One sample is destined for analysis, one is retained by the inspector, while the third is presented to the owner or seller of the remedy or his agent. When the remedy is in a container the contents of which are not sufficient for analysis if divided as outlined above, additional containers, similarly labelled and purporting to contain a similar remedy, shall be procured and the contents of two or more such containers shall then be thoroughly mixed before being divided into three parts. Where a remedy in a container is of a perishable nature, or where for any reason the opening of the container would interfere with the analysis of the remedy, unless such analysis were effected at the time of opening or immediately thereafter, at least three containers similarly marked and purporting to contain a similar agricultural remedy, shall be procured. The containers thus procured shall be split up into three groups, each of which shall contain one or more unopened containers and which shall further be dealt with as described above.

The owner of the remedy from which a sample is taken may claim from the Department of Agriculture an amount equal to the value thereof. 
Any officer of the Department of Customs and Excise authorised thereto by the Commissioner of Customs and Excise may detain any quantity of any remedy landed at or imported through any port or place in the Republic of South Africa and may take samples thereof. If an examination, analysis, or test of such samples shows that any such remedy does not comply with the requirements of the Act, the Minister may order that such remedy be destroyed or at the option of the importer be removed from the Republic within a specified period, or permit removal of the remedy from the port or place of entry subject to conditions he may determine. If any remedy which has been detained as outlined above is found to comply with the requirements of the Act no rent charges shall be payable by the importer.

2. Analyses.--The analyst to whom one part of the sample has been transmitted as outlined above is required, with all convenient speed, to analyse or test the remedy. The result of this analysis or test must be stated in a certificate in a prescribed form. This document will then form the basis of any legal procedure which may be initiated.

\section{Legislation administered by the Department of Agricultural Economics and Marketing}

\section{a) Inspection in terms of the Fruit Export Act (Act 27 of 1957) and the Agricultural Produce Export Act (Act 10 of 1959)}

The above-mentioned Acts require that all fresh fruit, meat or meat products, butter or butter substitutes, cheese, eggs, flowers, and any article whatever produced by or derived from farming operations or is a product directly derived from any such article and including any such substance or article which has undergone any change as a result of some process or treatment applied to it and any product intended for human consumption as food or drink which has been derived mainly from fruit of any kind or from one or more such substances or articles which are destined for export are subject to the regulations promulgated under these Acts. None of the above-mentioned products may be exported unless they have been inspected by the Department of Agricultural Economics and Marketing and after inspection branded by an inspector in a manner prescribed by regulation.

The legislation under these two Acts was enacted to protect valuable export markets in the face of strong international competition and prevent the dumping of undergrade produce on the overseas market.

1. Inspection.-- As far as pesticide residues on agricultural commodities are concerned, specific requirements are prescribed under the Citrus Export Regulations, Government Notice R617 of 24 April, 1964; the Subtropical Fruit Export Regulations, Government Notice R1372 of 10 September, 1965, and the Deciduous Fruit Export Regulations, Government Notice R1373 of 10 September, 1965. All three regulations 
stipulate that no fruit showing visible spray or dusting residues will be exported.

At present none of the export regulations mentioned above make provision for pesticide tolerances. For the past few years, however, a monitoring programme has been conducted to determine the extent and levels of pesticide residues. This venture is a collaborative one whereby inspectors appointed under Acts 27 of 1957 and 10 of 1959 take routine samples and submit these to residue laboratories of the Regulatory Services Section of the Soils Research Institute of the Department of Agriculture Technical Services. Whenever export residue levels coming close to the tolerance values are detected the grower concerned is approached in writing and warned that he should take meticulous care in implementing his pest-control programme.

With increasing discrimination by importing countries against pesticide residues in excess of established tolerances, legislation is at present being drafted whereby by regulation, the Department of Agricultural Economics and Marketing will be empowered to condemn shipments of export agricultural commodities on grounds of excess pesticide residues. Of necessity the tolerance levels which will be set will be the lowest of our regular customers, which may be below the levels acceptable for the local market.

\section{Legislation administered by the Department of Health}

a) Medical, Dental and Pharmacy Act (Act 13 of 1928)

1. Labelling.-- Government Notice 2000 of 15 December, 1966 prescribes that all compounds scheduled under the Fourth Division of the above-mentioned Act be classified as poisons. As far as agricultural and stock remedies are concerned, all products containing toxicants with an acute oral $\mathrm{LD}_{50}$ to rats of $50 \mathrm{mg}$./ $/ \mathrm{kg}$. or less are scheduled as poisons. When the Registering Officer (Act 36 of 1947) proposes registering a remedy containing a toxicant with an $\mathrm{LD}_{50}$ of less than $50 \mathrm{mg}$. $/ \mathrm{kg}$. he communicates his intention to the Department of Health which Department then includes the toxicant in the Fourth Schedule. All scheduled toxicants require the word "Poison" to appear in bold red print on a contrasting background and reference to the Fourth Schedule and the Act.

Furthermore in terms of Government Notice R340 of 17th March 1967 all pesticides containing organophosphates, carbamates or chlorinated hydrocarbons which are not included in the Fourth Schedule require the words "POISONOUS-DANGEROUS" to appear in print more conspicuous than the rest of the label. Following recent deliberations of the Standing Advisory Committee on Pesticides, this Regulation will be withdrawn.

2. Sale.-- Government Notice 2000 of 15 December, 1966 places certain restrictions on the sale of scheduled toxicants. Unless otherwise 
determined, scheduled poisons may not be offered for sale, stored, or exhibited on premises where other articles are normally stored or offered for sale except by a pharmacist or his unregistered assistant or apprentice or by a medical practitioner, dentist, or veterinarian in the course of their profession. The regulations entitle a magistrate, subject to certain conditions, to issue certificates to general dealers and cooperative societies to permit the storage and sale of certain specified poisons.

Departmental health inspectors conduct inspections of licensed premises to determine whether all requirements under the Act are observed and in the event of irregularities or convictions under the Act, such incidents are brought to the attention of the magistrate concerned who takes such evidence into consideration when renewing these poison certificates.

The sale of "poisons" by licensed dealers is subject to certain conditions. The dealer is required to keep a "poison book" in which all sales are recorded and which all buyers of such toxicants must sign. Prior to concluding a sale of a scheduled toxicant the licensed dealer or his duly authorised representative must satisfy himself as regards the bona fides of the buyer. Storage of scheduled "poisons" by licencees should occur under lock and key and all precautions must be taken to prevent contamination of other commodities. Premises and poison books are subject to inspection at all reasonable times.

Furthermore, while pharmacists can dispense scheduled remedies in labelled packages or containers of any weight or volume, general dealers and co-operative societies licensed to sell such remedies may only dispose of packages of not less than 14 pounds in the case of solids or five gallons in the case of liquids. This step was taken to prevent the sale of small packages by such dealers.

\section{b) Public Health Act (Act 36 of 1919)}

1. Notification of poisoning.-- In terms of Government Notice R253 of 20 February, 1970 pesticide poisoning is considered a notifiable disease. This requires the head of the family, or in his absence the nearest relative or, by default of these persons, the person attending the patient, or, in the absence of such individual, the occupier of the premises immediately to notify the local authorities of such poisoning. A similar responsibility is placed on a general practitioner where such a case comes to his attention. Local authorities are required, at the end of each week, to report all details of cases of notifiable diseases to the Chief Health Officer.

2. Fumigation.-- The Act empowers the Minister to issue regulations exercising control over hazardous professions and the prohibition of any fumigation, except under licence, with toxic gases. In terms of the above, regulations pertaining to hydrogen cyanide fumigation were 
issued in Government Notice 804 of 30 April, 1943, as amended by Notice 563 of 18 April, 1957. The regulations make provision for the issue of competence certificates by the Minister or a local authority as indicated in the First Schedule of the Act. At present hydrogen cyanide is the only fumigant officially approved by the authorities for the fumigation of dwelling places.

c) Foods, Drugs and Disinfectants Act (Act 13 of 1929)

1. Limits to toxic substances in preparations.--This Act empowers the Minister to issue regulations prescribing the substances and the quantities thereof which when added to or present in food or drug shall be deemed to render such food or drug unwholesome or injurious or dangerous for human consumption and use.

Government Notice 575 of 28 March, 1930 places a ban on the use in the packing of food on any packet, wrapper, container, or appliance of which the composition is such as to render the foodstuff with which it may come in contact unwholesome, injurious, or poisonous. The regulations also set limits on the quantity of arsenic, copper, lead, tin, and zinc which certain food commodities may contain.

Despite the above regulation, no legal tolerances have been set for pesticide residues in foodstuffs although some monitoring has been undertaken. The Department of Health, however, is at present preparing the necessary regulations to establish legal tolerances with concomitant expansion of residue analysis facilities to cope with the necessary residue control.

\section{Summary}

With certain exceptions all pesticides are subject to compulsory registration in South Africa. The Department of Agricultural Technical Services administers the scheme which caters for pesticides used in the agricultural, veterinary, public health, and domestic fields. Control over pesticides is operative at the federal level, there being no provincial control over the use of these products. Other legislation administered by the Department of Health and the Department of Agricultural Economics and Marketing exercises indirect control over specific facets such as residues on agricultural commodities marketed locally and overseas and the sale and storage of highly toxic products.

\section{Résumé *}

\section{La règlementation des pesticides en Afrique du Sud}

A quelques exceptions près, tous les pesticides sont soumis à un enregistrement obligatoire en Afrique du Sud. Le Ministère des Ser-

- Traduit par. R. Mestres. 
vices Techniques de l'Agriculture applique les dispositions qui régissent l'utilisation des pesticides à usages agricoles, vétérinaires, domestiques, ou utilisés pour la protection de la Santé Publique. La surveillance des pesticides a lieu à l'échelon fédéral, aucun contrôle de ces produits n'existant au niveau des provinces. En plus, réglementation sous la tutelle du Ministère de la Santé et le Ministère de l'Economie et des Marchés de l'Agriculture, exerce un contrôle indirect sur des aspects particuliers tels que les résidus sur les denrées agricoles commercialisées localement ou Outre-Mer et la vente et le stockage des produits hautement toxiques.

\section{Zusammenfassung *}

\section{Die Kontrolle von Pestiziden in Südafrika}

Mit gewissen Ausnahmen unterliegen alle Pestizide in Südafrika der zwangsweisen Registrierung. Die Abteilung der Agricultur-technischen Dienste handhabt das Schema, das für Pestizide bei Verwendung in der Landwirtschaft, im Veterinärwesen, im öffentlichen Gesundheitswesen und im Haushalt Sorge trägt. Die Kontrolle über die Pestizide ist auf Bundesebene wirksam, da keine Länderkontrolle über die Anwendung dieser Produkte besteht. Weitere Gesetzgebungen, erlassen durch die Abteilungen für Gesundheitswesen und für Landwirtschaft und Markt, übt die indirekte Kontrolle über spezielle Bereiche wie über die Rückstände an landwirtschaftlichen Waren aus, die lokal und über See gehandelt werden, sowie über den Verkauf und die Lagerung hochtoxischer Produkte.

* Úbersetzt von F. Bär. 